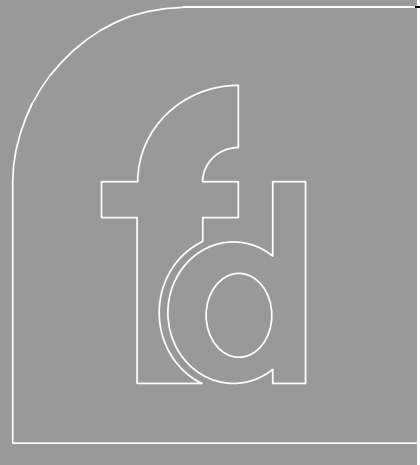

CONTENTS

Inactivated vaccine

live attenuated vaccine

Altemative strategies for vaccine administration

Animal models

used in evaluation of experimental vaccines

New generation vaccines

Expertopinion

Five-yearview

Information resources

Key issues

References

Affiliations

\footnotetext{
${ }^{\dagger}$ Author for correspondence Institute of Virology, Erasmus M C, D r M olewaterplein 50, PO Box 1738, 3000 D R Rotterdam,

The N etherlands

Tel.: +31 104088068

Fax: +31 104089485

stittelaar@viro.fgg.eur.nl
}

\section{KEYWORDS:}

measles, modified vaccinia virus ankara (M VA), Q uil A, vaccines

\title{
Vaccination against measles: a neverending story
}

\author{
Koert J Stittelaar ${ }^{\dagger}$, Rik L de Swart and Albert DM E Osterhaus
}

\begin{abstract}
Measles, a highly contagious viral disease, is a major childhood killer in developing countries, accounting foralmost 1 million deaths every yearglobally. Measles vinus nomally does not cause a persistent infection, no animal resenoirformeasles vinus exists, no vector is involved in its spread, only one serotype exists, the vinus is antigenically stable and vac cination with the currently used live attenuated vaccines proved to be highly effective in preventing disease. Therefore, theoretically measles should be considered eradicable. This article provides a review of past and current measles vaccination efforts and development and need of new generation experimental measlesvaccines.
\end{abstract}

Expert Rev. Vaccines 1(2), 151-159 (2002).

\section{Inactivated vaccine}

In theory, measles should be considered eradicable [1]. Large-scale vaccination against measles started in the 1960s. Children were vaccinated with formalin- or tween-ether inactivated, whole-virus vaccines adjuvated with alum. Although high seroconversion rates were observed $(>95 \%)$, the virus-neutralizing antibody titers were short-lasting, which necessitated multiple immunizations [2]. Furthermore, upon natural infection with measles virus (M V), children vaccinated with the inactivated vaccine developed enhanced disease, referred to as atypical measles $[3,4]$. Atypical measles was characterized by a prolonged high fever, an atypical rash and severe pneumonitis, often requiring hospitalization $[3,5,6]$. Abdominal pain, hepatic dysfunction, headache, eosinophilia, pleural effusions, hilar adenopathy and edema were also described [7]. As a result of this apparent immunopathological predisposition, the use of inactivated vaccines was abolished. It took long before the underlying mechanism was elucidated and even today we do not have a full understanding of the postulated immunepathogenesis. O ne of the first hypotheses was that the disease resulted from a lack of functional antibody against the fusion protein [8]. However, reproduction in macaques suggested that atypical measles rather resulted from previous priming for a $\mathrm{M} V$-specific, but nonprotective T-helper ( $\mathrm{Th}$ h) 2 response, leading to a strong anamnestic response following challenge resulting in immune complex formation and a pulmonary hypersensitivity response associated with eosinophilia [9].

\section{Live attenuated vaccine}

Based on the safety and efficacy data obtained in early studies with live attenuated measles virus preparations, vaccination against measles was persued again in the 1970s $[10,11]$. The application of live attenuated measles vaccines (LAV) resulted in an impressive decline of measles cases, especially in developed countries [12]. Furthermore, recent data suggests that vaccination against measles also reduces mortality from many other causes [13,14]. Other merits but also demerits of LAV are listed in BoX 1.

\section{Altemative strategies for vaccine} administration

Currently, the first LAV dose is given at an age between 9 and 15 months. At this age maternal antibodies, which interfere with replication of the vaccine virus, have vanished in most children. H owever, in developing countries, measl es frequently occurs at an early age ( $<9$ months) [15]. I deally, a measles vaccine should be effective when administered to very young infants in the presence of 
maternally-derived antibody. In an attempt to overcome vaccine neutralization by pre-existing immunity against $M V$, LAV has been applied with a dose 100- to 1000-fold higher. $\mathrm{H}$ owever, this led to a poorly understood increased mortality in girls in subsequent years as compared with infants vaccinated with standard titer LAV [16-19]. The currently used LAV, when parenterally administered, has proven to be quite successful. However, vaccine failures may, at least in part, be attributed to an inadequate vaccine-induced mucosal immunity - the current vaccine protects against measles but not necessarily against M V infection [20]. Vaccination strategies that would allow the induction of adequate mucosal immunity may have advantages in this respect. If this could be combined with the easy, inexpensive and safe administration of a stable vaccine, the efforts to eradicate $M V$ would be considerably facilitated. Besides the development of new generations of $M V$ vaccines, the question has been raised whether it would be feasible to apply the existing LAV via mucosal routes instead of the currently used parenteral routes. This could lead to an improved immune response at the site of virus entry. An additional advantage of this strategy might be

\section{Box 1. Advantages and disadvantages of live} attenuated vaccines.

Advantages Ref

Protective

Inexpensive

Balance immune response

Safe in immunocompetent individuals

More than 30 years of experience

Effective in measles control campaigns

Combination vaccine with rubella/mumps

\section{Disadvantages}

Less effective at young age

[70]

Interference with maternal antibody

Dependent on cold chain

Potential risk in immunocompromised individuals

Contraindication during pregnancy

Needles required

Molecular basis of attenuation is not known

Revertants not excluded

Possible contaminations introduced during production

Three components (vaccine, diluent and syringe)

Subclinical measles

$[76,77]$

Second dose required for effective control a more effective vaccination in the presence of pre-existing M V-neutralizing antibody [21,22]. For measles vaccines this phenomenon was reported years ago by 0 kune et al. and $U$ eda et al. [23,24]. They found that subcutaneously injected LAV was neutralized in the presence of low levels of neutralizing antibody, whereas LAV inhaled as aerosol was not. Since then, the concept of mucosal vaccination using the current LAV has been studied frequently. Different routes of administration have been explored [25]. Live measles vaccines for inhalation, already tested in thousands of children, usually show higher seroconversion rates than the LAV administered via a percutaneous injection [26-29]. H owever, the preparation of the aerosol vaccines requires advanced technologies to ensure their efficacy. Live measles vaccines for oral administration using enteric-coated tablets have been tested in laboratory animals with variable degrees of success putting this approach in arrears [30,31].

Despite the fact that ample experience has been obtained with the current LAV via the subcutaneous route, the same preparation but administrated via an alternative route will be considered a new vaccine according to current regulations [32]. Thus, as for new generation vaccine formulations, LAV administered via an alternative route would have to go through a complete process of registration and licensing.

\section{Animal models used in evaluation of experimental vaccines}

$O$ ver the past decades, several animal models have been used for studying the pathogenesis of measles as well as the evaluation of new vaccine candidates and vaccination strategies. Different rodents including mice [33], rats [34], ferrets [35] and hamsters [36] have been used to study aspects of experimental MV-induced encephalitis (EM VIE) as a model for neurologic disease and to study M V antigen-induced immune responses using EM VIE as a read-out for protection. These animal species are not susceptible to infection with wild type M V. H owever, several M V strains have been adapted for use in rodents, although virus replication is in general only detectable after intracerebral inoculation of very young animals. $\mathrm{CBA} / \mathrm{N}$ mice, grafted with human $\mathrm{PBL}$, were used to study $M V$ vaccine-induced protection in transfer experiments [37]. It needs no explaining that these animals do not develop measles-like disease.

The most successful rodent model for measles research appeared to be the cotton rat (Sigmodon hispidus) model [38-42]. Cotton rats can be infected intranasally with LAV and nonculture adapted wild type $M V$ isolates. The interference of preexisting virus neutralizing (VN) antibody with vaccination in cotton rats was addressed by transferring $M V$-specific antibodies of human- or cotton rat-origin and by vaccination of the offspring from seropositive dams $[41,43,44]$.

From the earliest days of measles vaccine research, primates have been used because of their high susceptibility to $M V$ [45]. Nonhuman primates including marmosets (Saguinus mystax), cynomolgus- and rhesus macaques (M acaca fascicularis and M acaca mulatta, respectively) and baboons (Papio hamadryas and Papio hybridus), proved to be most relevant 
for measles research $[46,47]$. $M$ acaques have been shown to be highly susceptible to M V infection as illustrated by natural outbreaks and the fact that intratracheal inoculation with 1 TCID 50 is sufficient to cause M V viremia [48]. It has also been shown that the pathogenesis of $\mathrm{M} V$ infection and development of specific immunity in macaques is largely similar to that in humans [48-50]. U pon intratracheal infection with wild type $M V$, infectious $M V$ can be quantitatively demonstrated in peripheral blood mononuclear cells (PBM C), lung lavage cells (LLC) and PEC, showing kinetics of viral loads that resemble $M V$ viremia in humans. The macaque models have allowed research on vaccine efficacy, in the presence and absence of passively acquired VN antibody [51-53]; vaccine safety [54], including comparison of the virulence of different virus strains [48,55]. Today, techniques and reagents to study immunological mechanisms in nonhuman primates such as T-cell proliferation assays, methods to detect specific antibody and reagents to measure cytokine production and cytokine producing cells, are to a large extent available.

Conventional mouse and rat-strains have been used for studying the antigenicity of $\mathrm{M} \mathrm{V}$-derived antigens, candidate vaccines and the type of immune response induced by these antigens. H owever, these studies are complicated by the fact that the type of immune reaction (Th1/Th2-like responses) varies among inbred laboratory animals. Transgenic and knockout mice have been used to study different aspects of MV-specific immune responses. Transgenic mice expressing human major histocompatibility complex (M HC) and CD 8 molecules mounted cytotoxic T-lymphocyte $(\mathrm{CTL})$ with similar specificities compared with humans with natural M V infection [56].

Although the pathogenesis of other morbillivirus infections in several animal species is often quite similar to that of $\mathrm{MV}$ infection in humans, models using other animal morbilliviruses, like canine distemper virus (CDV) in ferrets and dogs, are not selected for this review.

\section{New generation vaccines}

In the mid1980s the scientific community started working on the development of new generation vaccines. Vaccine effectiveness in children aged 4-5 months or younger and one-dose immunization were part of the new recommendations for $M V$ vaccine development. The development of more efficacious vaccines and vaccination strategies for human and animal virus infections is subject of considerable effort [57]. H ere, several approaches to develop a new generation of measles vaccines are addressed. A major theme was related to studies aiming at the induction of both $\mathrm{VN}$ antibodies and human lymphocyte antigen (HLA) class I-restricted CTL responses. The latter are considered to play a major role in the clearance of $M V{ }^{[58]}$ - their role in the elimination of $M V$ infected cells during infection is considered essential. To induce CTL or activate memory CTL, MV antigens have to enter the endogenous antigen processing and presentation pathway in an antigen-presenting cell (APC), which generally requires de novo protein synthesis [59]. Certain nonreplicating vaccine formulations however, may allow exogenous protein to enter this pathway. D evelopments in organic chemistry, biochemistry and molecular biology in the past decades have boosted efforts to formulate new generations of vaccines, which indeed allow the efficient induction of both VN antibodies and H LA class I-restricted CTL responses.

The new generation of candidate measles vaccines include: inactivated virus, live viral vectors, live bacterial vectors, subunit vaccines, synthetic vaccines and nucleic acid vaccines. TABLE 1 provides an enumeration of experimental measles vaccines showing the route of administration, the model and the parameters that were addressed. In addition, it is indicated when the vaccine candidate was tested in the presence of preexisting M V-neutralizing antibodies. Given the diversity of the experimental set-up for instance in terms of immunization dose, number of immunizations, time interval between different immunizations, time interval between immunization and challenge and the kind of challenge infection, it is difficult to venture expressing which vaccine candidate would be the best to take part in future vaccination strategies against measles.

Synthetic vaccines have been shown to be efficient activators of $C T L$ and to induce protective immune responses. H owever, such vaccines will most likely be unsuitable for vaccination of large populations because they would have to be 'tailor-made'. Epitope vaccines are designed for the individual on the basis of $\mathrm{M} \mathrm{HC}$ restriction, which might be a stumbling block. Peptides are weak immunogens that will require further immunopotentiation if they are to be effectivein vivo. The use of adjuvants may also reduce the amount of purified antigen required for successful immunization, thus making vaccine production more economical and practically feasible. At present the only adjuvants registered for human use are still aluminum hydroxide and aluminum phosphate. Synthetic vaccines would of course have several advantages, such as the option that their effectiveness would not necessarily be hampered by preexisting immunity against measles, the option to orchestrate the type of immune responses (immunomodulation) and good possibilities to be produced under GM P conditions [60,61]. Furthermore, they are relatively stable and cheap and sequence variations can easily be implemented whenever required. Although $\mathrm{VN}$ antibodies induced by different MV strains are known to be crossreactive, the reductionistic approach of a peptide-based vaccine may lead to mismatch between the vaccine and the wild type M V.

For measles, the only subunit and inactivated candidate vaccines that have been extensively studied are the Quil A-based preparations. M V-ISC O M S based on semipurified Q uil A have been shown to induce both strong M V-specific VN antibody, which are long lasting and CMI responses both in the absence and presence of pre-existing $\mathrm{VN}$ antibody. These vaccine candidates have been tested in different preclinical models and it would now be interesting to test them for their ability to induce protective immune responses in early life. In addition, because of the history of atypical measles associated with inactivated vaccines it will be necessary to test these Q uil A-based preparations in the macaque model for atypical measles.

Another novel vaccination approach which has been studied quite extensively for measles is nucleic acid vaccination (also 
Table 1. Enumeration of experimental measles vaccines.

\begin{tabular}{|c|c|c|c|c|c|c|c|}
\hline Category & Type & MV antigen & Admin. & Model & $\begin{array}{l}\text { MV Ab } \\
\text { transfer }\end{array}$ & Readout & Ref. \\
\hline Synthetic & $\begin{array}{l}\text { Lipopeptide } \\
\text { Peptide + CTB, IFA } \\
\text { Peptide + CTB } \\
\text { Peptide + Freund }\end{array}$ & $\begin{array}{l}\text { F CTL epitope } \\
\text { N, F CTL epitope } \\
\text { F T- B-cell epitope } \\
\text { H T- B-cell epitope }\end{array}$ & $\begin{array}{l}- \\
\text { in., ip. } \\
\text { in. } \\
\text { ip. }\end{array}$ & $\begin{array}{l}\text { In vitro } \\
\text { Mouse } \\
\text { Mouse } \\
\text { Mouse }\end{array}$ & $\begin{array}{l}- \\
- \\
\text { Yes }\end{array}$ & $\begin{array}{l}\mathrm{CTL} \\
\mathrm{CTL} \text {, protection } \\
\text { IgG, proliferation, protection } \\
\mathrm{VN} \text {, Ig }\end{array}$ & $\begin{array}{l}{[79]} \\
{[80]} \\
{[81]} \\
{[82]}\end{array}$ \\
\hline Subunit & Liposome & $\begin{array}{l}F, H \\
F, H \\
F, H \\
F, H \\
F, H \\
F, H \\
H\end{array}$ & $\begin{array}{l}\text { im. } \\
\text { im. } \\
\text { im. } \\
\text { im. } \\
\text { im. } \\
\text { sc. }\end{array}$ & $\begin{array}{l}\text { In vitro } \\
\text { Mouse } \\
\text { Macaque } \\
\text { Cotton rat } \\
\text { Macaque } \\
\text { Mac., mouse, rab. } \\
\text { Mouse, in vitro }\end{array}$ & $\begin{array}{l}- \\
- \\
- \\
\text { Yes } \\
- \\
-\end{array}$ & $\begin{array}{l}\text { CTL } \\
\text { IgG subclasseses, IgM, VN } \\
\text { VN } \\
\text { VN, protection } \\
\text { IgG, IgM, VN, CTL, proliferation, protection } \\
\text { DTH, VN, HI, IgG, T-cell clones } \\
\text { Proliferation }\end{array}$ & $\begin{array}{l}{[83]} \\
{[83]} \\
{[66]} \\
{[41]} \\
{[51]} \\
{[84]} \\
{[85]}\end{array}$ \\
\hline DNA & $\begin{array}{l}\text { Plasmid } \\
\text { ( } \pm \text { DOTAP) }\end{array}$ & $\begin{array}{l}\mathrm{N}, \mathrm{F}, \mathrm{H} \\
\mathrm{N}, \\
\mathrm{F}_{,}, \mathrm{H} \\
\mathrm{N}, \mathrm{F}, \mathrm{H} \\
\mathrm{H} \\
\mathrm{N} \\
\mathrm{H} \\
\mathrm{N} \text { (epitope) } \\
\mathrm{H} \\
\mathrm{F}_{,} \mathrm{H} \\
\mathrm{N} \\
\mathrm{H} \\
\mathrm{H}\end{array}$ & $\begin{array}{l}\text { Gene gun } \\
\text { Oral, PLGA } \\
\text { Gene gun, id. } \\
\text { ? } \\
\text { Gene gun, im. } \\
\text { im., in. } \\
? \text { ?. } \\
\text { id. } \\
\text { ib., in., oral, ij. } \\
\text { Gene gun } \\
\text { im. } \\
\text { im. } \\
\text { ip. }\end{array}$ & $\begin{array}{l}\text { Macaque } \\
\text { Mouse } \\
\text { Macaque } \\
\text { Cotton rat } \\
\text { Mouse } \\
\text { Mouse } \\
\text { Mouse } \\
\text { Mouse } \\
\text { Mouse } \\
\text { Mouse } \\
\text { Mouse } \\
\text { Mouse } \\
\text { Mouse }\end{array}$ & $\begin{array}{l}- \\
- \\
- \\
- \\
- \\
- \\
\text { Yes } \\
- \\
- \\
- \\
- \\
- \\
-\end{array}$ & $\begin{array}{l}\text { IFN- } \gamma \text {, IgG, IgM, VN, protection } \\
\text { IgG } \\
\text { CTL, VN, Ig, protection, AMS } \\
\text { IgG, protection } \\
\text { IgG subclasses } \\
\text { IFN- } \gamma \text {, IL4, CTL, IgG subclasses, IgA } \\
\text { Ig, IFN- } \gamma \text {, IL5, CTL, proliferation } \\
\text { CTL, protection } \\
\text { CTL } \\
\text { VN, IgG } \\
\text { IgG, protection } \\
\text { IgG subclasses, CTL, IL5, IFN- } \gamma \text {, Ig } \\
\text { IFN- } \gamma \text {, IL5, CTL, Ig }\end{array}$ & $\begin{array}{l}{[86]} \\
{[87]} \\
{[88]} \\
{[89]} \\
{[90]} \\
{[91]} \\
{[92]} \\
{[93]} \\
{[94]} \\
{[95]} \\
{[96]} \\
{[97]} \\
{[98]}\end{array}$ \\
\hline Inactivated & $\begin{array}{l}\text { Quil A-adjuvated } \\
\text { Alum-adjuvated }\end{array}$ & $\begin{array}{l}\text { BPL-inact. MV } \\
\text { BPL-inact. MV } \\
\text { BPL-inact. MV } \\
\text { BPL-inact. MV } \\
\text { formalin-inact. MV }\end{array}$ & $\begin{array}{l}\text { im. } \\
\text { im. } \\
\text { im. } \\
\text { im. }\end{array}$ & $\begin{array}{l}\text { In vitro } \\
\text { Mouse } \\
\text { Macaque } \\
\text { Cotton rat } \\
\text { Macaque }\end{array}$ & $\begin{array}{l}- \\
- \\
- \\
-\end{array}$ & $\begin{array}{l}\text { CTL } \\
\text { IgG subclasses, IgM, VN } \\
\text { VN } \\
C T L, \lg G \text {, IgM, VN, protection } \\
\text { IgG, IgA, IgE, VN, CTL, protection, AMS }\end{array}$ & $\begin{array}{l}{[83,88]} \\
{[83]} \\
{[66]} \\
{[41]} \\
{[9]}\end{array}$ \\
\hline Live & Attenuated & $\begin{array}{l}\text { MV Chicago-1 } \\
\text { MV Schwarz } \\
\text { MV Schwarz } \\
\text { MV E-M, MV E-Z } \\
\text { MV Schwarz } \\
\text { MV L-16 } \\
\text { MV-Moraten } \\
\text { MV- Moraten }\end{array}$ & $\begin{array}{l}\text { sc. } \\
? \\
\text { im. } \\
\text { im. } \\
\text { ip. } \\
\text { im., in., oral } \\
\text { im. } \\
\text { sc. }\end{array}$ & $\begin{array}{l}\text { Macaque } \\
\text { Mouse } \\
\text { Macaque } \\
\text { Cotton rat } \\
\text { Mouse } \\
\text { Macaque } \\
\text { Macaque } \\
\text { Macaque }\end{array}$ & $\begin{array}{l}\text { Yes } \\
\text { Yes } \\
\text { Yes } \\
- \\
- \\
-\end{array}$ & $\begin{array}{l}\text { IgG, IgA, IgE, VN, CTL, protection, AMS } \\
\text { IFN- } \gamma \text {, IL5, CTL, Ig, proliferation } \\
\text { IgG, IgM, VN, CTL, proliferation, protection } \\
\text { VN, protection } \\
\text { IgG subclasses, CTL, IL5, IFN- } \gamma \text {, Ig } \\
\text { VN, IgG, IgM, CD69, IL4, IFN- } \gamma \text {, protection } \\
\text { VN } \\
\text { VN, CTL, Ig, protection }\end{array}$ & $\begin{array}{l}{[9]} \\
{[92]} \\
{[51]} \\
{[41]} \\
{[97]} \\
{[31]} \\
{[99]} \\
{[88]}\end{array}$ \\
\hline
\end{tabular}

ALVAC: Strain of canarypox virus; BCG: Bacille Calmette-Guérin; BPL; $\beta$ - propiolactone; CD69: T-cell transmembrane activation marker; CTL: Cytotoxic T-cell assay; DCD4: In vivo depletion of CD4+ lymphocytes; DCD8: In vivo depletion of CD8+ lymphocytes; E-M: Edmonston-Moraten strain; E-Z: Edmonston-Zagreb strain; F: Measles virus fusion protein; H: Measles virus hemagglutinin; ib.: Transepithelial injection reaching the buccal mucosa; ic.: Intracutan; id.: Intradermal; ij.: Intrajejunal; im.: Intramuscular; in.: Intranasal; ip.: Intraperitoneal; ISCOM: Immune stimulating complex; it.: Intratracheal; L-16: Leningrad-16 strain; MVA: Modified vaccinia virus Ankara; N: Measles virus nucleoprotein; NYVAC: Highly attenuated strain of vaccinia virus; PIV3: Parainfluenza virus Type 3; sc.: Subcutaneous; VN: Measles virus-specific virus neutralizing antibody; VSV: Vesicular stomatitis virus. 
referred to as DNA vaccination). Plasmid DNA is very stable and the possibility of transdermal delivery, avoiding the use of needles, may improve overall compliance rates. A point of concern with regard to $D N A$ vaccination is the possibility that plasmid DNA integrates into genomic material of the host [62]. Whether or not plasmid DNA integration is a real safety issue remains elusive. The outcomes of different studies listed here are not unambiguous but generally it appears that the D N A measles candidate vaccines can efficiently prime the immune system. Although DNA vaccination against measles does not warrant protection, it may be further potentiated in heterologous primeboost vaccination regimens as has recently been demonstrated in combination with an edible candidate measles vaccine [63].

A completely different approach to induce a broadly reactive immune response, including $V N$ antibody and $C T L$ responses, is the use of bacterial and viral vectors, each with their own advantages and disadvantages. $0 \mathrm{f}$ this group, recombinant poxviruses have been studied most extensively and currently the most interesting vector is the replication-deficient poxvirus, modified vaccinia virus Ankara (M VA). D ue to its application in hundreds of thousands of people as a smallpox vaccine in the end-phase of the eradication of variola virus and studies in immunocompromised laboratory animals, it has developed an impressive efficacy and safety record.

Finally, we may contemplate the global eradication of M V. Although the complete elimination of $M V$ from whole continents was achieved with the currently used LAV, global eradication might demand alternative vaccination strategies, such as those being effective in the presence of maternal antibody and waning vaccineinduced immunity. Since the major burden of measles is in developing countries, the vaccination strategy must be able to overcome major logistical problems. A strategy that is based on two doses, or prime-boost regimens, will probably not be possible in certain areas. An initial immunization that only primes the immune system, which probably prevents severe disease, will be sufficient to reduce mortality and morbidity but may allow the virus to continue to circulate. 0 ptimally, at a very young age, one vaccine dose should induce long-lasting protective immunity that may not require an additional booster later in childhood. Due to the HIV epidemic, which is ongoing in certain target populations, safety in immunocompromised individuals must be guaranteed, although recent data showed no evidence for increased adverse events during a measles vaccination campaign in millions of African children [64,65]. In this respect inactivated vaccine candidates, such as the Q uil A-adjuvanted preparations, which show long-lasting high levels of $V N$ antibody after one dose and the poxvirus vector $M V A$, which is safe and proved to induce protection in the presence of pre existing VN antibody hold promise $[53,54,66]$. Since one-dose human neonatal vaccines have not been described before, future experiments should address the potential of such vaccine candidates in an immature immune system in the absence or presence of variable amounts of maternal-acquired measles antibody. Furthermore, the safety with regard to atypical measles can now be tested in the macaque model [9]. In addition the effectiveness and safety of this candidate measles vaccine should be addressed in LAV-vaccinated individuals and people that have had measles. Vaccination against measles is a neverending story because if measles is eradicated the human population should stay matched for reintroduction of $\mathrm{MV}$ via bioterroristic acts and other morbilliviruses via contacts with infected animals $[67,68]$.

\section{Expertopinion}

There is a growing opposition against vaccination due to reports and noises about adverse events associated with vaccination. Furthermore, the public support for vaccination against measles may weaken with the disappearance of cases with severe disease. U pon eradication of $\mathrm{MV}$ the necessity for continuing vaccination against measles will be even more unclear. There fore, important issues are to provide the public with information and to keep the total number of vaccinations restricted. Today, the LAV vaccine is available as part of the combination vaccine M M R but if the vaccine will be exchanged for a nonreplicating vaccine, which would result in dismantling the M M R vaccine, vaccine developers will need to work on other vaccine cocktails such as combination with DTP or a recombinant M VA containing multiple foreign genes.

\section{Five-year view}

In the next 5 years, no new vaccine against measles will be licensed. There are at this moment some promising candidate vaccines. The focus will be on $Q$ uil $A$-adjuvanted preparations and MVA-M V recombinants, which will be further tested in the preclinical models and subsequently in Phase I/II clinical trials in humans. M ore effort should be invested into testing these vaccine candidates for their ability to induce protection in early life. After having shown the efficacy of a candidate vaccine in adolescent or adult macaques, in the absence and presence of passively transferred M V neutralizing antibody, the efficacy should also be tested in newborn macaques with true maternal antibody.

D espite global efforts to control measles, a satisfactory level of control has not been reached. Therefore, key players in the fight against measles including the following organizations and/or partnerships: International American Red Cross, The International Federation of Red Cross and Red Crescent Societies, The U nited $\mathrm{N}$ ations (U N ) Foundation, Centers for D isease $C$ ontrol and Prevention (CDC), W orld $\mathrm{H}$ ealth $\mathrm{O}$ rganization (WHO), United Nations Children's Fund (UNICEF), Pan American $\mathrm{H}$ ealth $\mathrm{O}$ rganization (PAH O), Global Alliance for Vaccines and Immunization (GAVI), World Health Assembly, World Summit for Children, collectively have appointed strategic milestones for vaccination against measles. Currently, boosting vaccination coverage is attempted through massive 'catch-up', 'keep-up' and 'follow-up' campaigns, of which the effect will be evaluated between 2005-2010, depending on the country/region [112,113]. Application of this strategy has substantially reduced measles transmission in the industrialized world. For this approach the LAV were selected, postponing questions such as: 'do we need new measles vaccines' or 'can the present vaccine be used more efficiently' [114]. The global health partners will determine, on the basis of 
regional results (interruption of transmission etc.), whether the goal in vaccination against measles will finally be the achievement of a sustainable reduction of measles mortality, maintaining measles elimination or the global eradication of measles. This decision may be compromised by the fact that the feasibility for global eradication of measles dimishes with time, due to the increasing proportion of the human population that has been vaccinated instead of having experienced natural measles as a child.

\section{Information resources}

U seful websites:

- www.measlesinitiative.org

- www.who.int/vaccines-documents/D oxN ews/h4meas.htm

- www.who.int/vaccines-diseases/research/nva.shtml

- www.cdc.gov/health/measles.htm

- www.unicef.org/pubsgen/measles-statement

- www.measles.nl

\section{Key issues}

- Vaccination against measles can and will never be discontinued.

- In order to eliminate endemic circulation of measles virus (MV), a very high ( $\geq 95 \%$ ) level of vaccination coverage should be achieved.

- The current live attenuated vaccine against measles is safe, cheap and effective but alternative application routes may increase effectivity (compliance, seroconversion rate, cold chain maintenance) and safety (injection safety and waste disposal).

- In the long run, the current live attenuated vaccine against measles should be replaced by a nonreplicating vaccine.

- A vaccine against measles that is effective when administered at a young age in the presence of MV-specific neutralizing antibody would add significantly to the control of MV.

\section{References}

Papers of special note have been highlighted as:

- of interest

- of considerable interest

$\rightarrow$ Hinman A. Eradication of vaccine preventable diseases. Ann. Rev. Public $H$ ealth 20, 211-229 (1999).

$>2$ Rauh LW, Schmidt R. M easles immunization with killed virus vaccine. Am. J. Dis Child. 109, 232-237 (1965).

-3 Fulginiti VA, Eller JJ, D ownte AW, Kempe $\mathrm{CH}$. Altered reactivity to measles virus. Atypical measles in children previously immunized with inactivated virus vaccines. JAM A 202, 101-106 (1967).

-4 N ossal GJ. Inactivated measles vaccineand therisk of adverse events. Bull. World $H$ ealth O rgan 78, 224-225 (2000).

5 N ader PR, H orwitz MS, Rousseau J. Atypical exanthem following exposure to natural measles: eleven cases in children previously inoculated with killed vaccine. J. Pediatr. 72, 22-28 (1968).

6 Brodsky AL. Atypical measles. Severe illness

- in recipients of killed measles virus vaccine upon exposure to natural infection. JAM A 222, 1415-1416 (1972).

7 Fulginiti VA, H elfer RE. Atypical measlesin

- adolescent siblings 16 years after killed measles virus vaccine. JAM A 244, 804-806 (1980).

8 Merz DC, Scheid A, Choppin PW. Importance of antibodies to the fusion glycoprotein of paramyxoviruses in the prevention of spread of infection. J. Exp. M ed. 151, 275-288 (1980).
9 Polack FP, Auwaerter PG, Lee SH et al

-. Production of atypical measles in rhesus macaques: evidence for disease mediated by immune complex formation and eosinophils in the presence of fusioninhibiting antibody. Nat. M ed. 5, 629634 (1999).

10 Enders JF, Katz SL, M ilovanovic M V, H olloway A. Studies on an attenuated measles-virus vaccinel. D evelopment and preparation of the vaccine: technics for assay of effects of vaccination. N. Engl. J. M ed. 263, 153-159 (1960).

11 M CNair TF, Bonanno DE. Reactions to live measlesvirus vaccine in children previousy inoculated with killed-virus vaccine. N. Engl. J. M ed. 5, 248-251 (1967).

12 Clements CJ, CuttsFT. The epidemiology of measles thirty years of vaccination. Curr. Top. M icrobid. Immunol. 191, 13-33 (1995).

13 Aaby P. Assumptions and contradictions in - measles and measles immunization research: is measles good for something? Soc. Sci. M ed. 41, 673-686 (1995).

4 Shann F. Immunization-dramatic new evidence. P. N. G. M ed. J. 43, 24-29 (2000).

$15 \mathrm{H}$ artter HK, O yedele OI, Dietz K e al.

- Placental tranfer and decay of maternally acquired antimeases antibodies in N igerian children. Pediatr. Infect. Dis J. 19, 635-641 (2000).

16 Holt EA, M oulton LH, Siberry GK, $\mathrm{H}$ alsey NA. Differential mortality by measles vaccine titer and sex. J. Infect. Dis. 168, 1087-1096 (1993).
-17 Berry S, Hernandez H, Kanashiro R et al. Comparison of high titer EdmonstonZagreb, Biken-CAM and Schwarz measles vaccines in Peruvian infants. Pediatr. Infect. Dis. J 11, 822-827 (1992).

18 Garenne M, Leroy 0, Beau JP, Senel. Child mortality after high-titre measles vaccines:prospectivestudy in Senegal. Lancet 338, 903-907 (1991).

19 Aaby P, Samb B, Simondon F et al. Sexspecific differences in mortality after high-titre measles immunization in rural Senegal. Bull. World H ealth Organ 72, 761-770 (1994).

20 Paunio M, Peltola H, Valle M et al. Explosive school-based measles outbreak: intense exposure may have resulted in high risk, even among revaccinees. Am. J. Epidemiol. 148, 1103-1110 (1998).

21 Belyakov IM , M oss B, Strober W, Berzofsky

-. JA. M ucosal vaccination overcomes the barrier to recombinant vaccinia immunization caused by prexisting poxvirus immunity. Proc. Natl Acad. Sci. USA 96, 4512-4517 (1999).

-22 Belyakov IM, Wyatt LS, Ahlers JD et al. Induction of a mucosal cytotoxic Tlymphocyte response by intrarectal immunization with a replication-deficient recombinant vaccinia virus expressing human immunodeficiency virus 89.6 envelope protein. J. Virol. 72, 8264-8272 (1998).

-23 Okuno Y, U edaS, H osai H et al. Studies on the combined use of killed and live measles vaccines. II. Advantages of the inhalation method. Biken. J. 8, 81-85 (1965). 
-24 U eda S, H osai H, M inekawa Y, Okuno Y. Studies on the combined use of killed and live measles vaccines. 3. Conditions for the 'take' of live vaccine. Biken. J. 9, 97-101 (1966).

-25 CuttsFT, Clements CJ, BennettJV. Alternativeroutes of measles immunization: $\mathrm{a}$ review. Biologicals 25, 323-338 (1997).

-26 Sabin AB, Flores Arechiga A, Fernandez de Castro J et al. Successful immunization of infants with and without maternal antibody by aerosolized measles vaccine. II. Vaccine comparisons and evidence for multiple antibody response. JAM A 251, 2363-2371 (1984).

27 Dilraj $A$, Cutts FT, Fernandez de Castro J

-. et al. Response to different measles vaccine 39 strains given by aerosol and sc. routes to schoolchildren: a randomised trial. Lancet 355, 798-803 (2000).

-28 LiCalsi C, Christensen T, BennettJV, Phillips E, W itham C. D ry powder inhalation asa potential delivery method for vacanes. Vaccine17, 1796-1803 (1999).

29 LiC alsi C, M aniaci MJ, Christensen T

- et al. A powder formulation of measles vaccine for aerosol delivery. Vaccine 19, 2629-2636 (2001).

-30 N echaeva EA, Varaksin N, Ryabicheva T et al. Approaches to development of microencapsulated form of the live measles vaccine. Ann. NY Acad. Sci. 944, 180-186 (2001).

31 Stittelaar KJ, De Swart RL, Vos HW et al. Enteric application of a live attenuated measles vaccine does not induce protective immunity in a macaque model. Vaccine in Press (2002).

-32 Falk LA, Ball LK. Current status and future trends in vaccine regulation - USA. Vaccine 19, 1567-1572 (2001).

-33 N iewiesk S, Brinckmann U, Bankamp B et al. Susceptibility to measles virusinduced encephalitisin micecorrelates with impaired antigen presentation to cytotoxic T-Iymphocytes. J. Virol. 67, 75-81 (1993).

-34 Brinckmann U G, Bankamp B, Reich A, Ter M eulen V, Liebert UG. Efficacy of individual measles virus structural proteins in the protection of rats from measlesencephalitis. J. Gen. Virol. 72, 2491-2500 (1991).

- 35 Thormar H, M ehta PD, Barshatzky MR, Brown H R. M easles virus encephalitis in ferrets as a model for subacute sclerosing panencephalitis. Lab. Anim. Sci. 35, 229232 (1985).
36 Johnson KP. Experimental subacute sclerosing panencephalitis (SSPE) in the hamster. Adv. Exp. M ed. Biol. 134, 303309 (1981).

\section{$>37$}

uppes W, Smit V. Efficient replication of human immunodeficiency virusType 1 and measles virus in a human-to-mouse graft versus host disease model permits immunization research. J. Gen. Virol. 76, 2707-2715 (1995).

38 WydePR, Ambrose M W, Voss TG, M eyer $H L$, Gilbert BE. M easles virus replication in lungs of hispid cotton rats after intranasal inoculation. Proc. Soc. Exp. Biol. M ed. 201, 80-87 (1992).

Wyde PR, M oore-Poveda D, De Clercq E et al. U se of cotton rats to evaluate the efficacy of antivirals in treatment of measles virus infections. Antimicrob. Agents Chemother. 44, 1146-1152 (2001).

-40 WydePR, Moore-Poveda DK, Daley NJ, O shitani H. Replication of clinical measles virus strains in hispid cotton rats. Proc. Soc. Exp. Biol. M ed. 221, 53-62 (1999).

41 WydePR, Stittelaar KJ, O sterhaus A,

- Guzman E, Gilbert BE. Use of cotton rats for preclinical evaluation of measles vaccines. Vaccine 19, 42-53 (2000).

$>_{42}$ Niewiesk S. Studying experimental measles virus vaccines in the presence of maternal antibodies in the cotton rat model (Sigmodon hispidus). Vaccine 19, 22502253 (2001).

43 Schlereth B, RoseJK, Buonocore L, TerM eulen V, Niewiesk S. Succesfful vaccine-induced seroconversion by single dose immunization in the presence of measles virus-specific maternal antibodies J. Virol. 74, 4652-4657 (2000).

-44 Weidinger G, O hlmann M, Schlereth B, Sutter $\mathrm{G}$, N iewiesk $\mathrm{S}$. Vaccination with recombinant modified vaccinia virus Ankara protects against measles virus infection in the mouse and cotton rat model. Vaccine 19, 2764-2768 (2001).

45 Goldberger J and Anderson JF. An experimental demonstration of the presence of the virus of measles in the mixed buccal and nasal secretions. J. Am. M ed. Assoc. 57, 476-478 (1911).

46 Van Binnendijk RS, van der Heijden RWJ, Osterhaus AD M E. M onkeys in measles research, In: Ter M eulen V, Billeter M A, editors. M easles virus. Springer-Verlag, Berlin, Germany, 135-148 (1995).
47 Kobune F, Takahashi $\mathrm{H}$, Terao K et al. N onhuman primate models of measles. Lab. Anim. Sci. 46, 315-320 (1996).

48 Van Binnendijk RS, van der Heijden RWJ, Van Amerongen G, UytdeH aag FGCM , O sterhaus ADM E. Viral replication and development of specific immunity in macaques after infection with different meas es virus strains. J. Infect. D is. 170 , 443-448 (1994).

49 M cChesney M B, M iller CJ, Rota PA et al.

- Experimental measlesI. Pathogenesis in the normal and theimmunized host. Virology 233, 74-84 (1997).

${ }_{50}$ Zhu Y, H eath J, Collins et al. Experimental measles II. Infection and immunity in the rhesus macaque. Virology 233, 85-92 (1997).

51 Van Binnendijk RS, Poelen MCM, Van

- Amerongen G, DeVriesP, O sterhausADME. Protective immunity in macaques vaccinated with live attenuated, recombinant and subunit measles vaccines in the presence of passively acquired antibodies. J. Infect. Dis 175, 524-534 (1997).

52 Zhu Y-D, Rota P, Wyatt LS et al.

- Evaluation of recombinant vaccinia virus measl es vaccines in infant rhesus macaques with preexisting measles antibody. Virology 276, 202-213 (2000).

53 Stittelaar KJ, Wyatt LS, De Swart RL et al.

-. Protective immunity in macaques vaccinated with a M odified Vaccinia virus Ankara-based measles vaccine in the presence of passively acquired antibodies. J. Virol. 74, 4236-4243 (2000).

54 Stittelaar KJ, Kuiken T, De Swart RL et al.

- Safety of modified vaccinia virus Ankara (MVA) in immune-suppressed macaques. Vaccine 19, 3700-3709 (2001).

55 Auwarter PG, RotaPA, Elkins WR et al. $M$ easles virusinfection in Rhesus $M$ acaques: altered immune responses and comparison of the virulence of six different virus strains. J. Infect. Dis 180, 950-958 (1999).

$\checkmark 56$ Tishon A, LaFace DM, Lewicki $\mathrm{H}$ et al. Transgenic mice expressing human H LA and CD 8 molecules generate $\mathrm{H}$ LArestricted measles virus cytotoxic $T$ lymphocytes of the same specificity as humans with natural measles virus infection. Virology 275, 286-293 (2000).

$\checkmark 57$ Nossal GJ.The Global Alliance for Vaccines and Immunization-a millennial challenge. Nat. Immunol. 1, 5-8 (2000). 
58 Jaye A, M agnusen AF, Sadiq AD, Corrah $>11$ Ko B, RobertsD, Begg N et al. N eutralising

-. T, Whittle HC. Ex vivo analysis of cytotoxic T-lymphocytes to measles antigens during infection and after vaccination in Gambian children. J. Clin. Invest. 102, 1969-1977 (1998).

59 York IA and Rock KL. Antigen processing and presentation by the class I major histocompatibility complex. Ann. Rev. Immunol 14, 369-396 (1996).

-60 El Kasmi KC, M uller CP. N ew strategies for closing the gap of measles susceptibility in infants: towards vaccines compatible with current vaccination schedules. Vaccine 19, 2238-2244 (2001).

-61 El Kasmi KC, Theisen D, BronsNH e al. A hemagglutinin-derived peptide-vaccine ignored by virus-neutralizing passive antibodies, protects against murinemeases encephalitis. Vacaine17, 2436-2445 (1999).

-62 Siegrist CA. Potential advantages and risks of nucleic acid vaccinesfor infant immunization. Vacaine15, 798-800 (1997).

-63 Webster DE, Cooney M L, H uang Z et al. Successful boosting of a D N A measles immunization with an oral plant-derived measles virus vaccine. J. Virol. 76, 79107912 (2002).

64 Goon P, Cohen B, Jin L,W atkinsR, TudorWilliamsG. M M R vaccinein H IV-infected children - potential hazards? Vaccine 19, 3816-3819 (2001).

-65 Biellik R, Madema S, Taole A et al. First 5 years of measles elimination in southern Africa: 1996-2000. Lancet 359, 15641568 (2002).

66 Stittelaar KJ, Vos HW, Van Amerongen G

- et al. Longevity of neutralizing antibody levels in macaques vaccinated with $Q$ uil $A$ -adjuvated measles vaccine candidates. Vaccine in press (2002).

67 Stittelaar KJ and O sterhaus ADM E. $M V A$ : a cuckoo in the vaccine nest? Vaccine 19, v-vi (2001).

68 Osterhaus AD ME. Catastrophes after - crossing species barriers. Philos. Trans. R. Soc. Lond. B 356, 791-793 (2001).

-69 Virtanen M, PeltolaH, Paunio M, Heinonen OP. D ay-to-day reactogenicity and the heal thy vaccinee effect of measles-mumps-rubella vaccination. Pediatrics 106, E62 (2000).

70 Halsey NA, Boulos R, M odeR et al. Response to measles vaccine in $\mathrm{H}$ aitian infants 6 to 12 monthsold. N. Engl. J. M ed. 313, 544-549 (1985). antibody responses to two doses of measles vaccineat 5 and 13 months of age in the United Kingdom. Commun. Dis. Public $H$ ealth 2, 203-206 (1999).

-72 Saraswathy TS, Sinniah M, LeWS, Le $P C$. The value of potency testing of poliomyelitis and measles vaccines as an integral part of cold chain surveillance. Southeast Asian J. Trop. M ed. Public Health 24, 265-268 (1993).

-73 Levine M M. Livevirus vaccines in pregnancy. Risks and recommendations. Lancet 2, 34-38 (1974).

${ }_{74}$ RotaJS, Wang Z-D, Rota PA, Bellini WJ. Comparison of sequences of the $H, F$ and $\mathrm{N}$ coding genes of measles virus vaccine strains. VirusRes. 31, 317-330 (1994).

Tsang SX, Switzer WM , Shanmugam V et al. Evidence of avian leukosis virus subgroup $E$ and endogenous avian virus in measles and mumps vaccines derived from chicken cells: investigation of transmission to vaccine recipients. J. Virol. 73, 58435851 (1999).

-76 Pedersen IR, M ordhorst CH, Glikmann G, $M$ agnus von $H$. Subclinical measles infection in vaccinated seropositive individuals in arctic Greenland. Vaccine 7,

77 Whittle H C, Aaby P, Samb B et al. Effect of

-. subclinical infection on maintaining immunity against measles in vaccinated children in West Africa. Lancet 353, 98 - 102 (1999).

-78 CuttsFT, M arkowitz LE. Successes and failures in measles control. J. Infect. Dis. 170 (Suppl. 1), S32-S41 (1994).

79 Stittelaar KJ, H oogerhout $\mathrm{P}, \mathrm{O}$ vaa W et al. - In vitro processing and presentation of a lipidated cytotoxic T-cell epitope derived from measles virus fusion protein. Vaccine 20, 249-261 (2001).

80 Partidos CD, Vohra P, Steward M W. Priming of measles virus-specific CT $L$ responses after immunization with a CT L epitope linked to a fusogenic peptide. Virology 215, 107-110 (1996).

81 Hathaway LJ, Partidos CD, Vohra P, Steward $M W$. Induction of systemic immune responses to measles virus synthetic peptides administered intranasally. Vacine 13, 14951500 (1995).

El Kasmi KC, Fillon S, Theisen DM et al. N eutralization of measles virus wild type 345-348 (1989). isolates after immunization with a synthetic peptide vaccine which is not recognized by neutralizing passive antibodies. J. Gen. Virol. 81, 729-735 (2000).

$>83$ Stittelaar KJ, Boes J, Kersten GFA et al. In vivo antibody response and in vitro $C T L$ activation induced by selected measles vaccine candidates, prepared with purified Q uil A components. Vaccine 18, 24822493 (2000).

-84 DeVries P, Van Binnendijk RS, Van De $M$ arel $P$ et al. $M$ easles virus fusion protein presented in an immune-stimulating complex (iscom) induces haemolysisinhibiting and fusion-inhibiting antibodies, virus-specific T-cells and protection in mice. J. Gen. Virol. 69, 549-559 (1988).

-85 Garnier F, Forquet F, Bertolino P, Gerlier $D$. Enhancement of in vivo and in vitro Tcell response against measles virus haemagglutinin after its incorporation into liposomes: effect of the phospholipid composition. Vaccine 9, 340-345 (1991).

-86 Stittelaar KJ, De Swart RL, VosH W et al. Priming of measles-specific humoral- and cellular immune responses in macaques by D N A vaccination. Vaccine 20, 20222026 (2002).

87 Fooks AR, SharpeSA, ShallcrossJA, Clegg JC, Cranage M P. Induction of immunity using oral DNA vaccines expressing the measles virus nucleocapsid protein. Dev. Biol. (Basel) 104, 65- 71 (2000).

-88 Polack FP, Lee SH, Permar S et al. Succesful D N A immunization against measles:neutralizing antibody against either the hemagglutinin or fusion glycoprotein protects rhesus macaques without evidence of atypical measles. N at. M ed. 6, 776- 781 (2000).

-89 Schlereth B, Germann P-G, TerM eulen V, Niewiesk S. DN A vaccination with both the haemagglutinin and fusion proteins but not the nucleocapsid protein protectsagainst experimental meases virus infection. J. Gen. Virol. 81, 1321-1325 (2000).

-90 Torres CA, Yang K, M ustafa F, Robinson $H L$. DNA immunization: effect of secretion of DN A-expressed hemagglutinins on antibody responses. Vaccine 18, 805-814 (1999).

-91 Fennelly GJ, Khan SA, Abadi MA, Wild TF, Bloom BR. M ucosal DNA vaccine immunization against measles with a highly attenuated Shigella flexneri vector. J. Immunol. 162, 1603-1610 (1999). 
92 Siegrist CA, Barrios C, M artinez $X$ et al.

-. Influence of maternal antibodies on vaccine responses: inhibition of antibody but not T-cell responses allows successful early prime-boost strategies in mice. Eur. J. Immunol. 28, 4138-4148 (1998).

$\$ 93 \mathrm{H}$ su SC, Obeid OE, Collins M et al. Protective cytotoxic T-lymphocyte responses against paramyxoviruses induced by epitope-based DN A vaccines: involvement of IFN -gamma. Int. Immunol. 10, 1441-1447 (1998).

94 Etchart N, Buckland R, Liu M A, Wild F, Kaiserlian D. Class I-restricted CTL induction by mucosal immunization with naked DN A encoding measles virus hæemagglutinin. J. Gen. Virol. 78, 15771580 (1997).

-95 Yang K, M ustafaF, ValsamakisA et al. Early studies on DN A-based immunizations for measles virus. Vaccine 15, 888-891 (1997).

-96 Fooks AR, Jeevarajah D, Warnes A, Wilkinson GW, Clegg JC. Immunization of mice with plasmid DNA expressing the measles virus nucleoprotein gene. Viral Immunol. 9, 65-71 (1996).

$\$ 97$ M artinez X, Brandt C, Saddallah F et al. DN A immunization circumvents deficient induction of T-helper Type 1 and cytotoxic T-lymphocyte responses in neonates and during early life. Proc. Natl Acad. Sci. USA 94, 8726-8731 (1997).

98 Kovarik J, Gaillard M, M artinez X et al. Induction of adult-like antibody, Th1 and CTL responses to measles hemagglutinin by early life murine immunization with an attenuated vaccinia-derived NYVAC $(K 1 L)$ viral vector. Virology 285, 12-20 (2001).

99 Skiadopoulos M H, Surman SR, Riggs JM,

-. Collins PL, Murphy BR. A chimeric human-bovine parainfluenza virus Type 3 expressing measles virus hemagglutinin is attenuated for replication but is still immunogenic in rhesus monkeys. J. Virol. 75, 10498-10504 (2001).

100 Wild TF, Bernard A, Spehner D, D rillien R. Construction of vaccinia virus recombinants expressing several measles virus proteins and analysis of their efficacy in vaccination of mice. J. Gen. Virol. 73, 359-367 (1992)

-101 Drillien R, Spehner D, Kirn A et al. Protection of mice from fatal meases encephalitis by vaccination with vaccinia virus recombinants encoding either the hemagglutinin or the fusion protein. Proc. Natl Acad. Sci. USA 85, 1252-1256 (1988).

102 Bankamp B, Brinckmann UG, Reich A et al. M easles virus nucleocapsid protein protects rats from encephalitis. J. Virol. 65, 1695-1700 (1991).

103 Durbin AP, Skiadopoulos M H, M cAuliffe

- JM et al. Human parainfluenza virus Type 3 (PIV3) expressing the hemagglutinin protein of measles virus provides a potential method for immunization against measles virus and PIV3 in early infancy. J. Virol. 74, 6821-6831 (2000).

104 FooksAR, Jeevarajah D, Leej et al. Oral or parenteral administration of replicationdeficient adenoviruses expressing the measles virus haemagglutinin and fusion proteins: protective immune responses in rodents ]. Gen. Virol. 79, 1027-1031 (1998).

105 Fooks AR, Schadeck E, Liebert UG et al. $H$ igh-level expression of the measles virus nucleocapsid protein by using a replicationdeficient adenovirus vector: induction of an M HC-1-restricted CTL response and protection in a murine model. Virology 210, 456-465 (1995).

106 SharpeS, Fooks A, Lee J et al. Single oral immunization with replication deficient recombinant adenovirus elicits long-lived transgene-specific cellular and humoral immune responses. Virology 293, 210 -216 (2002).

107 Olszewska W, Erume J, Ripley J, Steward $M W$, Partidos CD. Immune responses and protection induced by mucosal and systemic immunisation with recombinant measles nucleoprotein in a mouse model of measles virus-induced encephalitis. Arch. Virol. 146, 293-302 (2001).
108 Maggi T, O ggioni M R, M edaglini D et al. Expression of measles virus antigens in Streptococcus gordonii. N ew M icrobiol. 23, 119-128 (2000).

109 Spreng S, Gentschev I, Goebel W et al. Salmonella vaccines secreting measles virus epitopes induce protectiveimmune responses against measles virus encephalitis. M icrobes Infect. 2, 1687-1692 (2000).

- 110 Verjans GM , Janssen R, UytdeH aag FG, van Doornik CE, Tommassen J. Intracellular processing and presentation of T-cell epitopes, expressed by recombinant Escherichia coli and Salmonella typhimurium, to human T-cells. Eur. J. Immunol. 25, 405-410 (1995).

111 Zhu Y D, Fennelly G, Miller C et al. Recombinant Bacille Calmette-Guerin expressing the measles virus nucleoprotein protects infant rhesus macaques from measles virus pneumonia. J. Infect. $D$ is. 176, 1445-1453 (1997).

112 WHO. Strategies for reducing global measles mortality. Wkly Epidemiol. Rec. 75, 411-416 (2000).

-113 WHO. M easles: progress towards gl obal control and regional elimination, 1990-1998. Wkly Epidemiol. Rec. 73, 389-394 (1998).

$\checkmark 114$ Davey S. M easles eradication still a long way off. Bull. World H ealth Organ. 79, 584-585 (2001).

\section{Affiliations}

- Koert J Stittelaar, PhD, Institute of Virology, Erasmus M C, D r M olewaterplein 50, PO Box 1738, 3000 D R Rotterdam, The N etherlands, Tel.: +31 10 4088068, Fax: +31 104089485 , stittelaar@viro.fgg.eur.nl

- Rik L deSwart, PhD, Institute of Virology, Erasmus M C, D r M olewaterplein 50, PO Box 1738, 3000 D R Rotterdam, The N etherlands, Tel.: +31 104088280, Fax: +31 104089482 , deswart@viro.fgg.eur.nl

- Prof. Albert DME Osterhaus, DVM, PhD, Institute of Virology,, Erasmus M C, D r M olewaterplein 50, PO Box 1738, 3000 DR Rotterdam, The N etherlands, Tel.: +31 10 4088066, Fax: +31 10 4089485, osterhaus@viro.fgg.eur.nl 